\title{
The Palliative Care Screening Tool as an instrument for recommending palliative care for older adults
}

\author{
Maykel Gonçalves Santa Clara' (ID) \\ Valmin Ramos Silva ${ }^{1} \mathbb{D}$ \\ Rosana Alves ${ }^{2}$ (D) \\ Maria Carlota de Rezende Coelho' (ID)
}

\section{Abstract}

The objective of the present study was to evaluate the use of the Palliative Care Screening Tool (PCST) for the recommendation of palliative care among older patients admitted to an Intensive Care Unit, as well as to evaluate the prevalence of basic diseases, religion and agreement between the results of the PCST and the Palliative Performance Scale (PPS). A cross-sectional, descriptive, analytical, retrospective, documental study with a quantitative approach was performed. Analysis of 594 medical records revealed that cardiovascular diseases accounted for $26.8 \%$ of hospitalizations among older adults, followed by neoplasia $20.2 \%$ and renal failure $16.8 \%$, and that aspects related to the religiosity and spirituality of the older adults were not considered. There was agreement of 1.0 between the PCST and PPS scales, as measured by the Kappa test, a score considered to be perfect. The PCST can therefore be considered an excellent tool for the evaluation of palliative care among older adults. It can be concluded that, in view of the significant level of agreement between the scales, new studies using the PCST with larger samples should be performed, with the aim of extending the use of the tool, and to assess if there is a need for adjustments aimed at adapting it more closely to the Brazilian population.

Keywords: Geriatrics. Palliative Care. Intensive Care Units.

\footnotetext{
Escola Superior de Ciências da Santa Casa de Misericórdia de Vitória, Pós-graduação em Políticas Públicas e Desenvolvimento Local, Departamento de Medicina. Vitória, ES, Brasil.

2 Universidade Federal do Espírito Santo, Departamento de Pediatria. Vitória, ES, Brasil.
}

The authors declare there are no conflicts of interest in relation to the present study.

No funding was received in relation to the present study.

Correpondence

Maykel Gonçalves Santa Clara

Received: July 10, 2019

maykelgsc@gmail.com 


\section{INTRODUCTION}

The practice of palliative care, despite being relatively recent, has as its cornerstone the integral treatment of the patient, the consideration of the finitude of life, respect for the patient's wishes, and the encouraging of therapy that aims to allow individuals to pass their remaining days with quality and dignity.

The beginning of the change in the approach to patient treatment, focusing on the individual rather than the disease, occurred in the 1960s with the advent of palliative care in the United Kingdom ${ }^{1}$. In 2002 the World Health Organization (WHO) defined palliative care, emphasizing the use and practices of measures to increase the quality of life of patients and their families ${ }^{2}$. In Brazil, according to a study conducted by the National Academy of Palliative Care (or ANCP) in 2018, there was a low number of palliative services in health institutions, which were unevenly distributed across the country ${ }^{3}$.

The consequences of the situational diagnosis of palliative care in Brazil are: patients indicated for intensive care unit (ICU) admission being treated in wards, due to the lack of available beds, thus contributing to increased morbidity and mortality ${ }^{4}$, the use, for patients with severe chronic comorbidities, of technologies which will not change the outcome and which increase the physical and psychological distress of patients and their families, resulting in the deterioration of the quality of death of the individual. The Economist magazine was emphatic in this regard when it assessed, in 2015, the quality of death in 80 countries, with Brazil ranking $42^{\text {nd }}$

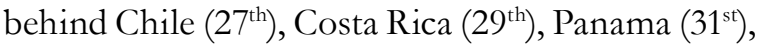

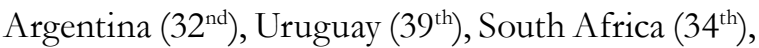
Uganda $\left(35^{\text {th }}\right)$, Mongolia $\left.\left(28^{\text {th }}\right)\right)$ and Malaysia $\left(38^{\text {th }}\right)^{5}$.

The older adult population is responsible for most ICU admissions and is the largest beneficiary of the practice of palliative care in the world ${ }^{6}$. According to data from the National Continuous Household Sample Survey - Characteristics of Residents and Households, produced by the Brazilian Institute of Geography and Statistics (or IBGE), the older population increased by 4.8 million from 2012 to 2017, thus highlighting the continuing trend. of aging of the Brazilian population?
The World Report on Aging and Health, published by the WHO in 2015, highlighted the need to transform health systems from curative forms focused on disease towards the implementation of comprehensive care centered on older adults ${ }^{8}$. In this sense, the need to identify older adults who would benefit from palliative care is evident. The Center to Advance Palliative Care (CAPC) developed the Palliative Care Screening Tool (PCST) for the indication of palliative care based on the following criteria: underlying disease, associated diseases, patient's functional condition and patient's personal condition, ultimately resulting in the need or not for palliative care ${ }^{9,10}$.

The Palliative Performance Scale (PPS) scale is widely used to indicate palliative care, allowing the patient prognosis and functionality to be established ${ }^{11,12}$. In the present study, we chose to use the PCST scale as we believe it is more comprehensive and, therefore, can accurately assess palliative criteria, with the aim of preventing patients indicated for palliative care suffering from therapeutic obstinacy, occupying ICU beds unnecessarily, and making them more likely to receive palliative care when indicated.

The aim of the present study was to evaluate the use of the PCST scale and assess its agreement with the PPS scale, as well as to describe the causes of hospitalization in older adults in palliative care, admitted to an Intensive Care Unit.

\section{METHODS}

A cross-sectional, descriptive, analytical, retrospective, documentary study with a quantitative approach was performed ${ }^{13}$. Primary data were used, originating from the inclusion of $100 \%$ of the medical records of patients evaluated, aged over 60 years, admitted to the ICU of a state hospital in Espírito Santo, Brazil, in 2017. No exclusion criteria were applied. The hospital in question is a general hospital with 286 active beds, of which 40 are intensive care beds.

In September 2015, a Multidisciplinary Palliative Care Committee was established at the hospital, consisting of two doctors, a psychologist and a social worker, who are exclusive to the service. When necessary, the team can also call on the support of 
a chaplain, dentist, speech therapist and nutritionist, among others.

The protocol for the inclusion of patients admitted to the ICU in palliative care flows as follows: the ICU duty physician requests an opinion from the palliative care committee based on clinical criteria, which then, using the PPS ${ }^{11}$ scale, confirms or not the indication of palliative care. When palliative care is indicated for the patient, he/she is transferred to a hospital ward, or when the hospital has no vacant beds, remains in the ICU under palliative care.

Two scales were used as research instruments. One was the PCST (Table 1), created by the Center to Advance Palliative Care (2004/2007), through the policy document in accordance with the Joint Commission on Accreditation of Healthcare Institutions (JCAHO) ${ }^{9}$. The scale assesses four criteria: underlying disease, associated diseases, patient's functional condition, and patient's personal condition. When the score (the sum of the four criteria) is greater than or equal to four points, the individual is considered to be in a suitable condition for palliative care.

The indication or not of palliative care according to the PCST scale is based on the sum of the items and is characterized as follows: up to two points, no indication of palliative care; up to three points patient should be kept under clinical observation; equal to or greater than four points consider indication of palliative care.

The other instrument used, the PPS scale (Table 2), allows a prognosis to be established and the patient's functionality to be evaluated. This scale analyzes five parameters: mobility, activity and evidence of disease, self-care, ingestion and state of consciousness and assigns values from $0 \%$ to $100 \%$, with $0 \%$ meaning death, and $100 \%$ meaning that the patient has no functional disorder. The PPS scale assesses the need for palliative care if the patient has a score below $40 \% 0^{11,12}$.

Table 1. Palliative Care Screening Tool (PCST) ${ }^{9,10}$. NY, USA, 2007.

Criterion Number 1 - Baseline Diseases - Two Points for Each Subitem

1. Cancer-metastasis or relapse

2. Advanced chronic obstructive pulmonary disease (COPD) - repeated exacerbations

3. Stroke (CVA) - reduction in motor function greater than or equal to $25 \%$

4. Severe renal impairment - creatinine clearance $<10 \mathrm{ml} / \mathrm{min}$

5. Severe heart failure - congestive heart failure $(\mathrm{CHF})$ with left ventricular ejection fraction $(\mathrm{EF})<25 \%$, cardiomyopathy or significant coronary insufficiency.

6.Other diseases limiting the patient's life

Criterion Number 2 - Associated Diseases - One point for each subitem:

1. Liver disease

2. Moderate Kidney Disease - creatinine clearance $<60 \mathrm{ml} / \mathrm{min}$.

3. Moderate COPD - stable clinical picture

4. Moderate CHF - stable clinical picture

5.Other associated diseases - all worth 1 point

Criterion Number 3 - Patient's Functional Condition

1.Patient's functional condition - this criterion assesses the degree of disability of the patient, taking into account the ability to perform normal daily activities, acts of personal care and the number of hours confined to bed or wheelchair. 2. Score ranges from 0 (fully independent, active, unrestricted patient) to 4 (fully dependent, needs full-time help, confined to bed or wheelchair).

Criterion 4 - Patient's personal conditions - one point for each subitem:

Patient's personal conditions - one point for each subitem:

1. Needs help with complex treatment decisions and undefined psychological or spiritual issues.

2. History of recent hospitalizations in emergency services.

3. Frequent hospitalizations for decompensation of underlying disease

4. Prolonged intensive care unit (ICU) admission or patient already in intensive care unit with poor prognosis

Source: Table adapted by Lucchetti of the Center to Advance Palliative Care (CAPC). Brazil, 2009. 
Table 2. Palliative Performance Scale (PPS) ${ }^{11,12}$. British Columbia, Canada, 2004.

\begin{tabular}{|c|c|c|c|c|c|}
\hline \multirow[b]{2}{*}{$\%$} & \multicolumn{5}{|c|}{ Items evaluated } \\
\hline & Ambulation & $\begin{array}{l}\text { Activity and evidence of } \\
\text { disease }\end{array}$ & Self-care & Ingestion & $\begin{array}{l}\text { Level of } \\
\text { consciousness }\end{array}$ \\
\hline 100 & Full & $\begin{array}{l}\text { Normal, without evidence } \\
\text { of disease }\end{array}$ & Full & Normal & Full \\
\hline 90 & Full & $\begin{array}{l}\text { Normal, some evidence of } \\
\text { the disease }\end{array}$ & Full & Normal & Full \\
\hline 80 & Full & $\begin{array}{l}\text { With effort, some evidence } \\
\text { of the disease }\end{array}$ & Full & Normal & Full \\
\hline 70 & Reduced & $\begin{array}{l}\text { Unable to work, some } \\
\text { evidence of the disease. }\end{array}$ & Full & $\begin{array}{l}\text { Normal or } \\
\text { reduced }\end{array}$ & Full \\
\hline 60 & Reduced & $\begin{array}{l}\text { Unable to perform hobbies, } \\
\text { significant illness }\end{array}$ & $\begin{array}{l}\text { Occasional } \\
\text { assistance }\end{array}$ & $\begin{array}{l}\text { Normal or } \\
\text { reduced }\end{array}$ & $\begin{array}{l}\text { Full or with periods } \\
\text { of confusion }\end{array}$ \\
\hline 50 & $\begin{array}{l}\text { Mainly sit or lie } \\
\text { down }\end{array}$ & $\begin{array}{l}\text { Unable for any work, } \\
\text { extensive illness }\end{array}$ & $\begin{array}{l}\text { Considerable } \\
\text { assistance }\end{array}$ & $\begin{array}{l}\text { Normal or } \\
\text { reduced }\end{array}$ & $\begin{array}{l}\text { Full or with periods } \\
\text { of confusion }\end{array}$ \\
\hline 40 & Bed-bound & Idem & $\begin{array}{l}\text { Almost } \\
\text { complete } \\
\text { assistance }\end{array}$ & $\begin{array}{l}\text { Normal or } \\
\text { reduced }\end{array}$ & $\begin{array}{l}\text { Full or with periods } \\
\text { of confusion }\end{array}$ \\
\hline 30 & Bed-bound & Idem & $\begin{array}{l}\text { Complete } \\
\text { dependency }\end{array}$ & Reduced & $\begin{array}{l}\text { Full or with periods } \\
\text { of confusion }\end{array}$ \\
\hline 20 & Bed-bound & Idem & Idem & $\begin{array}{l}\text { Ingestion } \\
\text { limited to sips }\end{array}$ & $\begin{array}{l}\text { Full or with periods } \\
\text { of confusion }\end{array}$ \\
\hline 10 & Bed-bound & Idem & Idem & $\begin{array}{l}\text { Mouth care } \\
\text { only }\end{array}$ & $\begin{array}{l}\text { Confused or in a } \\
\text { coma }\end{array}$ \\
\hline 0 & Death & - & - & - & - \\
\hline
\end{tabular}

Source: Table adapted by palliative care manual. Brazil, 2009, from the Victória Hospice Society.

The variables studied were: 1 ) all of the topics contained in the PCST scale, 2) the sum of PCST scores during hospitalization, 3 ) request for opinion of the palliative care committee, 4) whether the patient was placed in palliative care, 5) religion, 6) agreement between the PCST and PPS scales. Nominal categorical variables were organized by frequency and percentages and numerical variables as means.

The Kappa test was used to verify agreement between the PCST and PPS scales, with the reference values being: $<0$ No Agreement, $0-0.20$ Minimum Agreement, 0.21-0.40 Reasonable Agreement, 0.410.60 Moderate Agreement, 0.61-0.80 Substantial Agreement and 0.81-1.0 Perfect Agreement ${ }^{14}$.

The analysis was performed considering a significance level of $5 \%$, with $p$ values less than 0.05 considered significant.
The study was submitted to the Ethics Research Committee of the Santa Casa de Misericórdia de Vitória School of Science under protocol CAAE: 92777518.2.0000.5065 and approved under number $\mathrm{N}^{\circ} 7.793 .152$, following the provisions of CNS Resolution 466/12 regarding the requesting of a waiver of Informed Consent Forms.

\section{RESULTS}

A total of 974 medical records were identified, corresponding to the total number of hospitalizations in 2017, of which 11 were excluded due to lack of data and 369 because they were from patients under 60 years of age. Thus, the final sample was $594(61.6 \%)$ records. Of these, $44.5 \%$ were male and $55.5 \%$ were female, and the mean age was 75.2 years. 
To highlight the prevalence of underlying diseases among older patients admitted to the hospital ICU, the location of the study, Table 3 was created. Of the 594 patient records, it was found that $268(45.1 \%)$ were hospitalized due to decompensation of the underlying disease according to PCST criterion number 1 and 326 (55.9\%) were hospitalized for reasons not associated with the underlying disease.

Cardiovascular diseases corresponded to $26.8 \%$ (sequelae of stroke and congestive heart failure) of hospitalizations, followed by neoplasms (20.1\%) and renal failure $(16.8 \%)$.

In 2017, 74 patients were placed in palliative care, evaluated by the committee of the hospital studied, using the PPS scale. To assess the comprehensiveness of the PCST, it was applied to the 594 medical records of ICU patients, and the kappa coefficient of agreement between the PCST and PPS scales was calculated (Table 4). A total of 218 medical records of patients with a score greater than or equal to four were subsequently identified, as shown in Table 5.

Table 3. Basic illnesses of hospitalizations in intensive care units of Espírito Santo State Hospital, Brazil, in 2017 $(\mathrm{N}=268)$.

\begin{tabular}{ll}
\hline Underlying illnesses & Number $(\%)$ \\
Cancer & $54(20.1)$ \\
Stroke Sequel & $50(18.6)$ \\
Renal insufficiency & $45(16.8)$ \\
Dementia & $36(13.4)$ \\
Chronic obstructive pulmonary disease & $24(8.9)$ \\
Cirrhosis & $23(8.6)$ \\
Congestive heart failure & $22(8.2)$ \\
Diabetes & $8(3)$ \\
Neuropathy & $2(0.8)$ \\
Advanced spondyloarthropathy & $1(0.4)$ \\
Fistula & $1(0.4)$ \\
Myelodysplastic syndrome & $1(0.4)$ \\
Trauma sequelae & $1(0.4)$ \\
\hline Total & $268(100)$ \\
\hline
\end{tabular}

Source: Records of the intensive care unit of the State Hospital of Espírito Santo State, Brazil, in 2017.

Table 4. Kappa coefficient of agreement between the PCST and PPS scales for older patients evaluated by the palliative care committee ( $\mathrm{N}=75$ ), admitted to the intensive care units of the Espírito Santo State Hospital, Brazil, 2017.

\begin{tabular}{llll}
\hline \multirow{2}{*}{ Palliative Care Screening Tool } & \multicolumn{3}{c}{ Palliative Performance Scale } \\
\cline { 2 - 4 } & Non-palliative & Palliative & Total \\
\hline Request for opinion not required & 1 & 0 & 1 \\
Request for opinion required & 0 & 74 & 74 \\
Total & 1 & 74 & 75 \\
\hline
\end{tabular}

Kappa agreement coefficient observed: $1.00, p<0.0001$.

Source: records of the intensive care units of the Espírito Santo State Hospital, Brasil, 2017. 
Table 5. Application of PCST and request for opinions/responses requested by the medical team, for older adults hospitalized in the intensive care units of the Espírito Santo State Hospital, Brazil, in 2017 (N=218).

\begin{tabular}{lll}
\hline Opinion & $\begin{array}{l}\text { PCST Score } \geq 4 \\
\text { Number (Percentage) } \\
\mathrm{n}(\%)\end{array}$ & $\begin{array}{l}\text { Confidence Interval } \\
\text { Opinion not requested }\end{array}$ \\
$\begin{array}{l}\text { Patients effectively placed in palliative care } \\
\text { (clinical evaluation and application of PPS scale) }\end{array}$ & $74(34)$ & $27.7-40.2$ \\
$\begin{array}{l}\text { Opinions not provided due to death. } \\
\text { Opinion requested, but PCST score }<4 \text { and denied }\end{array}$ & $28(12.9)$ & $8.4-17.3$ \\
by Palliative Commission following application of PPS & $1(0.4)$ & -- \\
\hline Total & $218(100)$ & \\
\hline
\end{tabular}

Confidence interval of $95 \%$.

Source: Records of the intensive care units of the Espírito Santo State Hospital, Brazil, in 2017.

When analyzing the religion of the older adults evaluated in this study who were effectively placed in palliative care, there was a predominance of Catholics (32.4\%), followed by evangelicals (11.9\%), atheists $(2.7 \%)$, and records where religion was not informed (50\%).

\section{DISCUSSION}

Ministry of Health Resolution No. 41/2018 was a milestone for the practice of palliative care in Brazil as it regulated this practice as a health policy. The resolution establishes that any person affected by a life-threatening disease, whether acute or chronic, will be offered palliative care following the diagnosis of their condition ${ }^{15}$.

However, early and correct diagnosis has been a major challenge in healthcare institutions, due to a number of institutional barriers, such as a lack of sufficient beds for palliative patients, an inadequate number of palliative care committees, non-uniformity of training for health professionals on palliative care and few palliative care programs in health institutions ${ }^{16}$.

The situational analysis and indications for structuring palliative care programs in Brazil by the National Academy of Palliative Care (or ANCP) in 2018 found 177 palliative care services in the country, of which $50 \%$ were concentrated in the southeastern region, and with only 13 teams in the north-northeast region ${ }^{3}$, demonstrating the great inequality in the availability of palliative care in the Brazilian health system.

In Brazil, older adults represent $52 \%$ of ICU admissions in public services, and spend $60 \%$ of the daily and financial resources available for this sector ${ }^{17}$. A higher value was found in the present study, which corroborates the importance of this population in terms of the occupation of ICU beds, and the need to evaluate whether every patient truly benefits from using all the technological and structural arsenal of equipment available in these environments, or if they have serious chronic diseases that from a palliative perspective could have improved quality of life and be treated mostly outside the intensive care unit environment.

According to data from the global atlas of worldwide palliative care, it is estimated that over 20 million people each year require end-of-life palliative care $^{7}$. Most (69\%) are older patients, and there is a slight predominance of males $(52 \%)^{6}$, whereas in the data found in the present study there was a predominance of females.

The comorbidity that led to the largest number of hospitalizations of older adults in the ICUs studied was cardiovascular diseases $(26.8 \%$ ), followed by neoplasms $(20.2 \%)$. These data are similar to those found by the World Health Organization in the 2014 global atlas of palliative care ${ }^{6}$. 
According to Table 5, of the 218 records of patients with a PCST score greater than or equal to 4, only 102 requests for opinions were made. This implies that $47 \%$ of opinions on patients that could benefit from palliative care were effectively requested. Thus, it can be deduced that 115 patients who were recommended for evaluation by the palliative team were not given this opportunity. This fact also highlights the high degree of sensitivity of the scale and reinforces the possibility of using it as a palliative care evaluation ${ }^{10}$, although it cannot be ruled out that the high sensitivity observed may overestimate the number of patients referred for palliative care.

Still in relation to Table 4, the Kappa agreement coefficient among patients for whom the PCST and PPS were applied (75 records) was calculated. The value found between the scales was 1.00 , considered perfect agreement ${ }^{14}$, reinforcing the potential of its use as an assessment tool for identifying the need for palliative care, as the PPS allows prognosis and patient functionality to be evaluated and the PCST evaluates four criteria: underlying disease, associated diseases, the patient's functional condition and the patient's personal condition, thus analyzing individuals more broadly, with a greater possibility of identifying patients who will benefit from palliative care ${ }^{9-12}$.

These results also demonstrate a probable failure to identify possible palliative patients, leading to the occupation of important ICU beds that could be vacated if the palliative team identified the possibility of treating patients in wards or at home. Another important issue to be considered is the increase in costs from unnecessary procedures and technologies leading to the increased physical and psychological suffering of patients and their families through therapy that increases the length of hospitalization without changing the outcome of the condition ${ }^{18}$.

While not the objective of the present study, based on the idea that the comprehensiveness of care that should also value subjective aspects, it was found that the aspects related to the religiosity and spirituality of patients were not considered. The perception of physicians on religiosity/spirituality, as well as staff training in multidisciplinary spiritual care, can contribute to the quality of end-of-life care in older adults ${ }^{19}$.
In addition, spirituality is an important factor for patients with severe illness and who are indicated for palliative care, as it represents a source of comfort, strength, faith, as well as of coping and a guide to conducting one's life ${ }^{20}$.

Brazil is a country with a predominance of the Christian religion and the largest number of Catholics in the world, data that coincide with the study in question. According to data from the 2010 IBGE census, $64.6 \%$ of the Brazilian population practices the Catholic religion, followed by $22.2 \%$ evangelicals, $8 \%$ atheists and $2 \%$ who are followers of spiritualism ${ }^{21}$. It is noteworthy that in $50 \%$ of the medical records there were no records on the religion of the patients. This data demonstrates the need to pay attention to and register such information, due to the value of spiritual aspects for the health of individuals.

The present study contributes to the expansion of scientific knowledge among health professionals, as well as to the improvement of the management of both ICU beds and the palliative care service. One of the limitations of the study was the low number of medical records for a comparative study between the scales by statistical methods. Thus, further studies with larger samples should be performed to confirm or otherwise the results identified in this study.

\section{CONCLUSION}

The study identified perfect agreement between the PCST and PPS scales, and found that the PCST, due to its high sensitivity, is an important tool in indicating patients for palliative care. It is notable that 143 individuals with a proven indication for palliative care were not even evaluated by the palliative commission, indicating the need for a more efficient service in the hospital under study. Cancer, stroke sequelae, renal failure, dementia, chronic obstructive pulmonary disease, cirrhosis, and congestive heart failure were the most frequent causes of the need for palliative care. Despite the recognized role of spirituality in palliative care, in half of the cases there was no record of the religion of the patient.

Edited by: Tamires Carneiro Oliveira Mendes 


\section{REFERENCES}

1. Gomes Z, Othero B. Cuidados paliativos. Estud Av [Internet]. 2016 [acesso em 22 maio 2018];30(88):155-66. Disponível em: http://www. scielo.br/scielo.php?script $=$ sci_arttext\&pid $=$ S010340142016000300155\&lng=en\&nrm=iso

2. Wold Health Organization. Palliative Care. Cancer control: knowledge into action: WHO guide for effective programmes [Internet]. Geneva: WHO; 2007 [acesso em 25 maio 2018]. Disponível em: http://www.who.int/cancer/publications/cancer_ control_palliative/en/

3. Academia Nacional de Cuidados Paliativos. Análise situacional e recomendações para estruturação de programas de cuidados paliativos no Brasil [Internet]. São Paulo: ANCP; 2018 [acesso em 11 mar. 2019]. Disponível em: https://paliativo.org.br/wp-content/ uploads/2018/12/ANALISE-SITUACIONAL_ ANCP-18122018.pdf

4. Urizzi F, Tanita MT, Festti J, Cardoso LTQ, Matsuo T, Grion CMC. Caring for critically ill patients outside intensive care units due to full units: a cohort study. Clinics [Internet]. 2017 [acesso em 09 Jul. 2018];72(9):568-74. Disponível em: http://www. scielo.br/scielo.php?script $=$ sci_arttext\&pid $=$ S1807$59322017000900568 \& \operatorname{lng}=$ en\& $\mathrm{nrm}=$ iso

5. Economist Inteligence Unit. The 2015 quality of death index: Ranking palliative care around the world [Internet]. London: EIU; 2015 [acesso em 01 fev. 2019]. Disponível em: https://eiuperspectives. economist.com/sites/default/files/2015\%20EIU\%20 Quality $\% 20$ of $\% 20$ Death $\% 20$ Index $\% 20$ Oct $\% 20$ 29\%20FINAL.pdf

6. Wold Health Organization. Global atlas of Palliative Care at the end of life [Internet]. Geneva: WHO; 2014 [acesso em 01 fev. 2019]. Disponível em: https://www.who.int/nmh/Global_Atlas_of_ Palliative_Care.pdf

7. Instituto Brasileiro de Geografia e Estatística. Pesquisa Nacional por Amostra de Domicílios Contínua [Internet]. Rio de Janeiro: IBGE; 2018 [acesso em 04 abr. 2019].Disponível em: www.ibge.gov.br

8. Pupim T. Cuidados paliativos em geriatria: concepção da equipe multiprofissional. Vitória [dissertação na Internet]: Escola Superior de Ciências da Santa Casa de Misericórdia de Vitória; 2017 [acesso em 20 mar. 2019]. Disponível em: http://www.emescam.br/ arquivos/pos/stricto/dissertacoes/131_CAROLINE_ TESSINARI_PUPIM.pdf
9. Center to Advance Palliative Care. Crosswalk of JCAHO Standards and Palliative Care - Policies, procedures and assessment tools [Internet]. New York: JCAHO; 2007 [acesso em 22 maio 2018]. Disponível em: https://www.palliativedrugs.com/ download/JCAHO-crosswalk.pdf

10. Lucchetti G, Badan M, Ramos C, Faria C, Alessandra $\mathrm{G}$, Sueli $\mathrm{P}$, et al. Uso de uma escala de triagem para cuidados paliativos nos idosos de uma instituição de longa permanência. Geriatr Gerontol Aging [Internet]. 2018 [acesso em 23 maio 2018]. Disponível em: http://ggaging.com/details/299/pt-BR

11. Academia Nacional de Cuidados Paliativos. Manual de cuidados paliativos [Internet]. Rio de Janeiro: ANCP; 2009 [acesso em 23 maio 2018]. Disponível em: http://www.santacasasp.org.br/upSrv01/ up_publicacoes/8011/10577_Manual $\% 20 \mathrm{de} \% 20$ Cuidados\%20Paliativos.pdf $>$. Acesso em: 25 mai 2018. ISBN 978-85-89718-27-1

12. Victoria Hospice Society. Palliative Performance Scale (PPSv2) [Internet]. Columbia: VHS; 2004 [acesso em 30 jul. 2018]. Disponível em: http:// www.npcrc.org/files/news/palliative_performance_ scale_PPSv2.pdf

13. Fontelles MJ, Simões MG, Farias SH, Fontelles RGS. Metodologia da pesquisa científica: diretrizes para a elaboração de um protocolo de pesquisa. Rev Para Med [Internet]. 2009 [acesso em 12 out. 2019];23(3):1-8. Disponível em: http:// cienciasecognicao.org/redeneuro/wp-content/ uploads/2019/06/DIRETRIZES-PARA-AELABORA $\%$ C3\%87\%C3\%83O-DE-UMPROTOCOLO-DE-PESQUISA.pdf

14. Landis J, Koch G. The Measurement of Observer Agreement for Categorical Data. Biometrics [Internet]. 1977 [acesso em 10 jan. 2019];33:15974. Disponível em: https://www.dentalage.co.uk/ wpcontent/uploads/2014/09/landis_jr__koch_ gg_1977_kappa_and_observer_agreement.pdf

15. Brasil. Resolução no 41, de 31 de outubro de 2018. Dispõe sobre as diretrizes para a organização dos cuidados paliativos, à luz dos cuidados continuados integrados, no âmbito Sistema Único de Saúde (SUS). Diário Oficial da União. 23 nov. 2018. Seção 1:276. Disponível em: http://www.in.gov.br/materia/-/ asset_publisher/Kujrw0TZC2Mb/content/ id/51520746/do1-2018-11-23-resolucao-n-41-de-31de-outubro-de-2018-51520710 
16. Sarradon-Eck A, Besle S, Troian J, Capodano G, Mancini J. Understanding the barriers to introducing early palliative care for patients with advanced cancer: a qualitative study. J Palliat Med [Internet]. 2018 [acesso em 04 fev. 2019]. Disponível em: https://www. liebertpub.com/doi/abs/10.1089/jpm.2018.0338?rfr_ dat $=$ cr_pub\%3Dpubmed\&url_ver=Z39.88-2003\&rfr_ $\mathrm{id}=$ ori $\% 3$ Arid $\% 3$ Acrossref.org\&journalCode=jpm

17. Bonfada D, Santos M, Lima K, Garcia-Altés A. Análise de sobrevida de idosos internados em Unidades de Terapia Intensiva. Rev Bras Geriatr Gerontol [Internet]. 2017 [acesso em 12 fev. 2019];20(2):198-206. Disponível em: http://www.scielo.br/pdf/rbgg/v20n2/ pt_1809-9823-rbgg-20-02-00197.pdf

18. Coelho CBT, Yankaskas JR. Novos conceitos em cuidados paliativos na unidade de terapia intensiva. Rev Bras Ter Intensiva [Internet]. 2017 [acesso em 12 fev. 2019];29(2):222-30. Disponível em: http://www.scielo.br/scielo.php?script $=$ sci_ arttext\&pid=S0103507X2017000200222\&lng=en
19. Gijsberts MHE, Van der Steen JT, Hertogh CMPM, Deliens L. Spiritual care provided by nursing home physicians: a nationwide survey. BMJ Support Palliat Care [Internet]. 2019 [acesso em 04 fev. 2019]. Disponível em: https://spcare.bmj.com/content/ early/2019/04/04/bmjspcare-2018-001756.long

20. Silva DIS, Silveira DT. Cuidados paliativos: desafio para a gestão e políticas em saúde. Rev Eletrônica Gest Saúde [Internet]. 2015 [acesso em 05 set. 2018];06(1):501-13. Disponível em: https://www.lume. ufrgs.br/bitstream/handle/10183/131418/000980055. pdf? sequence $=1 \&$ is Allowed $=y$

21. Instituto Brasileiro de Geografia e Estatística. Censo demográfico 2010. Características gerais da população, religião e pessoas com deficiência [Internet]. Rio de Janeiro: IBGE; 2010 [acesso em 12 fev. 2019]. Disponível em: www.ibge.gov.br 